\title{
SISTEM AGRIBISNIS USAHA TERNAK AYAM RAS PETELUR (STUDI KASUS CV MULAWARMAN FARM) DI KECAMATAN GADINGREJO KABUPATEN PRINGSEWU
}

\author{
(Agribusiness System Of Layer Chickens Farming: Case Study in CV Mulawarman Farm in Gadingrejo \\ Subdistrict of Pringsewu Regency)
}

Pram Andika, Sudarma Widjaya, Adia Nugraha

\begin{abstract}
Jurusan Agribisnis, Fakultas Pertanian, Universitas Lampung, Jl. Prof. Dr. Soemantri Brodjonegoro No.1 Bandar Lampung 35145, Telp.082372071717,e-mail:pramandika55@yahoo.com
\end{abstract}

\begin{abstract}
The research aims to determine the supply of production facilities, financial feasibility, and marketing system. This research is a case study at CV Mulawarman Farm in Gadingrejo Subdistrict of Pringsewu Regency. The data was collected in April 2017 and analyzed by qualitative descriptive and finance feasibilities analysis. The result showed that the supply of production facilities at CV Mulawarman Farm did not fully met the expectation because the supply of nipple drinker still occurred delayed for the far distance. The development business at layer chickens farming of CV Mulawarman Farm was profitable enough up to population scaled of 75,000 heads (25 percent larger than the previous population). The egg marketing system of CV Mulawarman Farm distributed to the regular customers that located spreadly in Bandar Lampung, Pringsewu, Tanggamus, and Pesawaran in which the highest percentage of egg marketing distribution was in Bandar Lampung.
\end{abstract}

Key words: agribusiness system, financial feasibility, laying chicken

\section{PENDAHULUAN}

Pembangunan pertanian yang berkelanjutan sebaiknya dilakukan secara merata, agar dapat berkontribusi pada terwujudnya ketahanan pangan (Arifin 2005). Provinsi Lampung lebih terkenal dengan hasil pertanian di subsektor perkebunan dan tanaman pangan, namun subsektor peternakan juga memiliki potensi yang baik untuk dikembangkan di Provinsi Lampung. Kontribusi subsektor peternakan terhadap PDRB Provinsi Lampung selalu mengalami kenaikan sejak tahun 2012 - 2014 dengan persentase kenaikan rata-rata 11,76 persen (BPS Lampung 2015).

Komoditas peternakan di Provinsi Lampung terbagi menjadi komoditas unggulan dan prospektif (Dinas Peternakan dan Kesehatan Hewan Provinsi Lampung, 2008). Ayam ras petelur merupakan salah satu ternak komoditas unggulan di Provinsi Lampung. Potensi pengembangan peternakan ayam ras petelur di Provinsi Lampung cukup menjanjikan karena telur ayam ras mendominasi produksi telur nasional sebanyak 1,82 juta ton telur yang dikonsumsi masyarakat, 71 persen atau 1,29 juta ton telur dihasilkan dari ayam ras petelur (Kata Data News and Research 2015).
Kabupaten Pringsewu merupakan salah satu daerah yang akan dikembangkan menjadi daerah sentra peternakan ayam ras petelur di Provinsi Lampung. Perusahaan ternak ayam ras petelur CV Mulawarman Farm yang secara geografis terletak di Kecamatan Gadingrejo merupakan usaha ternak ayam ras petelur terbesar di Kabupaten Pringsewu. Perusahaan ternak ini menerapkan sistem agribisnis yang terdiri dari subsistem penyediaan sarana produksi, usaha tani, pemasaran dan jasa layanan pendukung.

Jumlah populasi ayam yang semakin besar pada kegiatan budidaya ayam ras petelur menjadi tantangan tersendiri bagi perusahaan ternak $\mathrm{CV}$ Mulawarman Farm agar dapat mempersiapkan sarana produksi secara memadai dan tepat. Besarnya populasi ayam yang dibudidayakan akan berbanding lurus terhadap tingginya biaya-biaya, penerimaan bahkan pendapatan. Analisis kelayakan finansial diperlukan untuk mengetahui apakah usaha tersebut menguntungkan untuk dikembangkan.

Kegiatan pemasaran merupakan bagian penting dari suatu usaha untuk memastikan produk yang dihasilkan sampai ke konsumen. Semakin tumbuhnya usaha-usaha sejenis akan menjadi pesaing dari perusahaan ternak CV Mulawarman 
Farm ketika akan memasarkan produknya. Berdasarkan latar belakang masalah tersebut, penelitian ini bertujuan untuk mengetahui sistem penyediaan sarana produksi, kelayakan finansial, dan sistem pemasaran telur pada perusahaan ternak ayam ras petelur CV Mulawarman Farm.

\section{METODE PENELITIAN}

Metode penelitian yang digunakan adalah metode studi kasus di perusahaan ternak ayam ras petelur CV Mulawarman Farm pada bulan April 2017. Data yang digunakan adalah data primer data sekunder. Data primer diperoleh melalui wawancara langsung dengan pemilik usaha, kepala kandang dan operator kandang menggunakan alat bantu kuisioner, sedangkan data sekunder diperoleh dari jurnal, peneltian terdahulu, Dinas Peternakan, Badan Pusat Statistik, dan data internal dari perusahaan ternak ayam ras petelur $\mathrm{CV}$ Mulawarman Farm.

Analisis yang digunakan meliputi analisis deskriptif kualitatif dan analisis finansial yang meliputi perhitungan NPV, IRR, PP dan BEP dengan rumus sebagai berikut :

$\mathrm{NPV}=\sum_{\mathrm{i}=0}^{\mathrm{n}} \frac{\mathrm{Bt}-\mathrm{Ct}}{(1+\mathrm{i})^{\mathrm{t}}}$

Keterangan :

$$
\begin{aligned}
\mathrm{NPV}= & \text { Net Present Value (nilai neto sekarang) } \\
\mathrm{Bt}= & \text { Penerimaan } / \text { manfaat bersih pada tahun } \\
& \text { ke- } \mathrm{t} \\
\mathrm{Ct}= & \text { Biaya }(\text { cost }) \text { pada tahun ke-t } \\
\mathrm{t} & =\text { Waktu } / \text { umur ekonomis usaha ternak } \\
& (\text { tahun) } \\
\mathrm{n} \quad= & \text { Umur proyek (tahun) } \\
\mathrm{i} & =\text { Discount Rate (tingkat suku bunga) }
\end{aligned}
$$

$\operatorname{IRR}=i_{1}+\left[\frac{\mathrm{NPV}_{1}}{\mathrm{NPV}_{2}-\mathrm{NPV}_{1}}\right]\left(\mathrm{i}_{2}-\mathrm{i}_{1}\right)$

Keterangan :

$$
\begin{array}{ll}
\mathrm{NPV}_{1} & =\text { Present Value positif } \\
\mathrm{NPV}_{2} & =\text { Present Value negatif } \\
\mathrm{i}_{1} & =\text { Discount factor, jika NPV }>0 \\
\dot{i}_{2} & =\text { Discount factor, jika NPV }<0 \\
\mathrm{PP} & =\frac{\text { investasi awal }}{\text { Arus kas (benefit) }} \times 1 \text { tahun ....... }
\end{array}
$$

$\mathrm{BEP}$ Produksi $=\frac{\mathrm{FC}}{\mathrm{P}-\mathrm{AVC}}$

$$
\text { BEP Harga }=\frac{\mathrm{TC}}{\mathrm{Q}}
$$

Keterangan :

$$
\begin{array}{ll}
\mathrm{TC} & =\text { Total Biaya } \\
\mathrm{FC} & =\text { Biaya Tetap } \\
\mathrm{AVC} & =\text { Biaya Variabel Rata-Rata } \\
\mathrm{P} & =\text { Harga Jual Produk } \\
\mathrm{Q} & =\text { Total Produksi }
\end{array}
$$

\section{HASIL DAN PEMBAHASAN}

\section{Gambaran Umum Usaha}

Perusahaan ternak ayam ras petelur CV Mulawarman Farm merupakan usaha ternak mandiri milik perseorangan yang bergerak pada bidang budidaya ayam ras petelur yang berlokasi di Desa Tegal Sari Kecamatan Gadingrejo Kabupaten Pringsewu. Perusahaan ternak ini membudidayakan 60.000 ekor ayam ras petelur dan memiliki 33 buah kandang yang terbagi menjadi dua lokasi kandang yaitu kandang barat dan timur. Kandang pada perusahaan ternak ini dilengkapi dengan gudang yang berguna untuk kegiatan packing dan penyimpanan telur.

Perusahaan ternak ayam ras petelur $\mathrm{CV}$ Mulawarman Farm memiliki 29 tenaga kerja dengan berbagai posisi dalam menjalankan kegiatan usaha budidaya ayam ras petelur. Tenaga kerja pada perusahaan ternak ini berdasarkan posisinya meliputi 15 orang operator kandang, 6 orang tenaga gudang, 1 orang kepala kandang, 4 orang sopir, dan 3 orang juru masak. Perusahaan ternak ini berencana melakukan pengembangan populasi sebesar 25 persen dari jumlah populasi semula yaitu 60.000 ekor menjadi 75.000 ekor.

\section{Analisis Penyediaan Sarana Produksi}

Penyediaan sarana produksi pada perusahaan ternak ini meliputi pengadaan kandang, peralatan penunjang kandang, bibit, pakan, vaksin dan tenaga kerja.

\section{Kandang}

Biaya yang dibutuhkan untuk pembangunan kandang pada perusahaan ternak ayam ras petelur CV Mulawarman Farm adalah Rp220.000.000,00 per unit. Kandang memiliki umur ekonomis 15 tahun dan pemeliharaan serta perbaikan kandang dilakukan setiap dua tahun sekali. Perusahaan ternak ayam ras petelur CV Mulawarman Farm saat ini memiliki 33 unit kandang dengan populasi ayam sebanyak 46.692 ekor dari populasi awal yaitu 60.000 ekor. Rata-rata total populasi ayam adalah 1.415 ekor per kandang. Perusahaan ternak 
ini akan melakukan pengembangan populasi ayam menjadi 75.000 ekor atau sebesar 25 persen dari populasi sebelumnya. Kapasitas maksimal kandang yang mampu menampung $2.000-2.500$ ekor per kandang, menunjukkan bahwa kandang yang dimiliki jumlahnya akan mampu menampung seluruh populasi ternak baik sebelum melakukan pengembangan populasi maupun ketika akan melakukan pengembangan populasi ayam ras petelur.

\section{Peralatan Penunjang Kandang}

Peralatan penunjang kandang terdiri dari nipple drinker (tempat minum), mesin pemanas dan wadah air. Biaya pengadaan untuk nipple drinker, mesin pemanas dan wadah air masing-masing sebesar Rp9.200,00 per pasang, Rp700.000,00 per unit dan Rp200.000,00 per unit. Total kepemilikan awal nipple drinker 18.750 sebanyak pasang, mesin pemanas 31 unit, dan wadah air 31 unit. Berdasarkan hasil penelitian, perusahaan ternak ayam ras petelur CV Mulawarman Farm melakukan pengadaan kembali nipple drinker sebanyak 1.136 pasang dengan biaya pengadaan sebesar Rp10.451.200,00 yang diperoleh dari Medan.

Pengadaan tersebut dilakukan karena nipple drinker mengalami kerusakan dan sudah tidak bisa digunakan. Pengadaan nipple drinker masih mengalami keterlambatan karena jarak tempuh yang jauh. Tindakan yang dilakukan oleh perusaahaan ternak ini ketika terjadi keterlambatan pengiriman nipple drinker yaitu memindahkan ayamnya ke kandang lainnya yang nipple drinker masih berfungsi dengan baik.

\section{Pengadaan Bibit}

Bibit yang digunakan adalah bibit DOC strain isa brown dengan pertimbangan bahwa bibit jenis ini lebih tahan penyakit dan merupakan jenis bibit unggul karena memiliki performance produksi telur lebih dari 90 persen (Genetics 2009). Pengadaan bibit dilakukan pada saat awal periode produksi sesuai dengan jumlah yang dibutuhkan dengan biaya sebesar Rp7.900,00 per ekor yang diperoleh dari PT. Chieljedang Feed yang berlokasi Tanjung Bintang, Lampung Selatan.

\section{Penyediaan Pakan}

Pakan yang digunakan merupakan jenis pakan jadi yang berbentuk crumble (kapsul kecil). Pakan jenis ini digunakan mulai dari ayam DOC sampai ayam afkir. Kebutuhan pakan pada perusahaan ternak ayam ras petelur CV Mulawarman Farm adalah $146.940 \mathrm{~kg}$ dengan frekuensi pengadaan pakan satu kali dalam satu bulan. Harga beli pakan sebesar Rp5.250,00 per kg yang didapatkan dari PT CJ Cheiljedang Feed Lampung Selatan, sehingga total biaya pengadaan pakan sebesar Rp771.433.551,00 per bulan.

Stok pakan yang selalu tersedia dan jaraknya yang tidak terlalu jauh menjadi pertimbangan pemilik perusahaan ternak CV Mulawarman Farm untuk membeli pakan dari perusahaan tersebut. Hal tersebut sejalan dengan penelitian Hidayat, Sulaksana dan Sumantri (2016) yang menyatakan bahwa Pengadaan pakan memanfaatkan penyedia sarana produksi yang berlokasi tidak jauh dari lokasi kandang.

\section{Vaksinasi}

Pengadaan vaksin pada perusahaan ternak ayam ras petelur CV Mulawarman Farm berasal dari PT. Medion yaitu perusahaan yang khusus memproduksi obat-obatan bagi hewan ternak. Vaksinasi yang dilakukan sebanyak tiga kali dengan total biaya yang dikeluarkan untuk vaksinasi terhadap seluruh populasi ayam yang ada (46.692 ekor) sebesar Rp28.015.200,00 dimana rincian lebih lanjut adalah $\mathrm{Rp} 14.007 .600,00$ untuk vaksinasi pertama, Rp9.338.400,00 untuk vaksinasi kedua, dan Rp4.669.200,00 untuk vaksinasi ketiga.

\section{Pengadaan Tenaga Kerja}

Pegadaan tenaga kerja berasal dari lingkungan sekitar maupun daerah lain. Kriteria pendidikan yang ditetapkan oleh pemilik perusahaan ternak ayam ras petelur CV Mulawarman Farm pada proses seleksi yaitu tenaga kerja lulusan Sekolah Menengah Pertama (SMP) maupun Sekolah Menangah Atas (SMA). Jumlah tenaga kerja CV Mulawarman saat ini adalah 29 orang yang terbagi ke berbagai posisi seperti kepala kandang, operator kandang, sopir, juru masak dan tenaga gudang. Biaya yang dikeluarkan untuk keseluruhan tenaga kerja sebesar Rp39.700.000,00 per bulan.

\section{Budidaya Ayam Ras Petelur}

Usia ayam yang dibudidayakan saat melakukan penelitian yaitu 18 bulan. Pemberian pakan dilakukan dengan frekuensi dua kali sehari yaitu pada pagi hari dan siang hari dengan rata-rata kebutuhan pakan ayam yaitu 104,90 gram per ekor per hari. Jika dibandingkan dengan periode 
sebelumnya saat usia ayam sama, konsumsi pakan yaitu 110 gram per ekor per hari. Hal tersebut menunjukkan bahwa terjadi penurunan konsumsi pakan. Hal ini disebabkan oleh penyakit, kebersihan kandang yang kurang terjaga, dan perubahan cuaca yang ekstrim.

Penyakit yang menyerang ternak ayam ras petelur adalah penyakit coryza yang ditandai dengan keluarnya air dari hidung. Pengobatan jenis penyakit ini dengan cara pemberian vaksin coryza dengan cara menyuntik paha ayam dan dosisnya adalah $0,5 \mathrm{ml}$ per ekor. Vaksinasi untuk pencegahan penyakit dan meningkatkan kekebalan tubuh hewan ternak adalah vaksinasi ND IB emulsion (1,5 dosis per ekor) dan fortelit $(1,5 \mathrm{ml}$ per ekor) dengan cara mencampurkan kedalam air minum. Vaksinasi tersebut dilakukan terhadap keseluruhan populasi ayam yang masih hidup yaitu 46.692 ekor, sehingga total penggunaan vaksin coryza adalah $23.346 \mathrm{ml}$, ND IB emulsion 70.038 dosis, dan fortelit $70.038 \mathrm{ml}$.

Teserangnya ternak ayam oleh penyakit secara langsung berdampak terhadap penurunan performa produksi ayam. Rata-rata persentase performa produksi ayam ras petelur saat periode produksi sebelumnya adalah 82 persen, sedangkan persentase performa ayam ras petelur pada perusahaan ternak ayam ras petelur $\mathrm{CV}$ Mulawarman Farm saat penelitian adalah 80,42 persen yang berarti bahwa terjadi penurunan performa produksi sebesar 1,58 persen.

\section{Analisis Usaha}

\section{Biaya Investasi}

Biaya investasi dan peralatan pada perusahaan ternak ayam ras petelur CV Mulawarman Farm tersebut meliputi bangunan kandang, gudang, peralatan penunjang kandang, wadah telur dan kendaraan. Total investasi dari perusahaan ternak tersebut adalah Rp8.248.240.000,00. Nilai investasi kandang merupakan nilai investasi terbesar yaitu Rp7.260.000.000,00 atau 88,02 persen dari total biaya investasi.

\section{Biaya Operasional}

Biaya operasional pada perusahaan ternak ayam ras petelur CV Mulawarman Farm meliputi biaya bibit ayam DOC, pakan, vaksin, tenaga kerja, transportasi, listrik, gas, PBB dan pemeliharaan kandang yang disajikan pada Tabel 1 dan 2 .

\section{Cash flow CV Mulawarman Farm}

Cash flow bertujuan untuk mengetahui biaya total (arus kas keluar) dan penerimaan (arus kas masuk) perusahaan ternak ayam ras petelur $\mathrm{CV}$ Mulawarman Farm selama 15 tahun.

Rata-rata biaya operasional yang dikeluarkan per tahun oleh perusahaan ternak ayam ras petelur $\mathrm{CV}$ Mulawarman Farm sebelum pengembangan populasi ayamnya adalah Rp12.932.751.227,00, per tahun, sedangkan setelah pengembangan populasi ayam menjadi 75.000 ekor biaya operasional yang dikeluarkan menjadi Rp16.293.447.250,00 per tahun. Kenaikankenaikan biaya operasional yang terjadi meliputi kenaikan biaya pengadaan bibit ayam DOC, pakan, vaksin, tenaga kerja dan transportasi. Biaya operasional terbesar yang dikeluarkan oleh perusahaan ternak ini merupakan biaya pakan ternak baik itu sebelum maupun setelah pengembangan populasi ayam.

Tabel 1. Rata-rata biaya operasional perusahaan ternak ayam ras petelur $\mathrm{CV}$ Mulawarman Farm sebelum pengembangan populasi

\begin{tabular}{clr}
\hline No. & \multicolumn{1}{c}{ Uraian } & \multicolumn{1}{c}{$\begin{array}{c}\text { Biaya sebelum } \\
\text { pengembangan }(\mathrm{Rp})\end{array}$} \\
\hline 1. & Bibit ayam DOC & $474.000 .000,00$ \\
2. & Pakan & $11.312 .708 .827,00$ \\
3. & Vaksin & $241.382 .400,00$ \\
4. & Tenaga kerja & $476.400 .000,00$ \\
5. & Transportasi & $378.000 .000,00$ \\
6. & Listrik & $4.200 .000,00$ \\
7. & Gas & $1.320 .000,00$ \\
8. & PBB & $4.000 .000,00$ \\
9. & Pemeliharaan kandang & $41.400 .000,00$ \\
\hline \multicolumn{2}{c}{ Total }
\end{tabular}

Tabel 2. Rata-rata biaya operasional perusahaan ternak ayam ras petelur $\mathrm{CV}$ Mulawarman Farm setelah pengembangan populasi ayam

\begin{tabular}{clr}
\hline No & \multicolumn{1}{c}{ Uraian } & $\begin{array}{r}\text { Biaya setelah } \\
\text { pengembangan }(\mathrm{Rp})\end{array}$ \\
\hline 1. & Bibit ayam DOC & $592.500 .000,00$ \\
2. & Pakan & $14.306 .339 .250,00$ \\
3. & Vaksin & $280.278 .000,00$ \\
4. & Tenaga kerja & $591.600 .000,00$ \\
5. & Transportasi & $472.500 .000,00$ \\
6. & Listrik & $4.200 .000,00$ \\
7. & Gas & $1.320 .000,00$ \\
8. & PBB & $4.000 .000,00$ \\
9. & Pemeliharaan kandang & $41.400 .000,00$ \\
\hline \multicolumn{2}{c}{ Total }
\end{tabular}




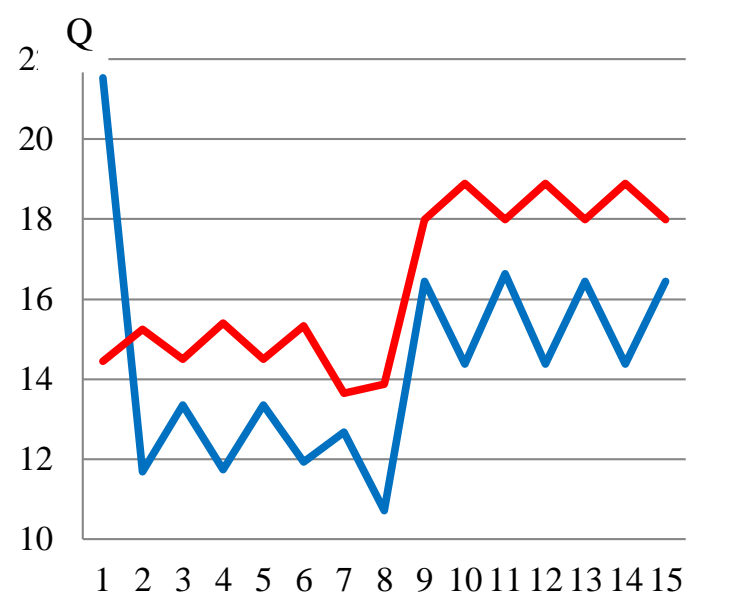

Gambar 1. Cash flow perusahan ternak ayam ras petelur CV Mulawarman Farm

Keterangan :

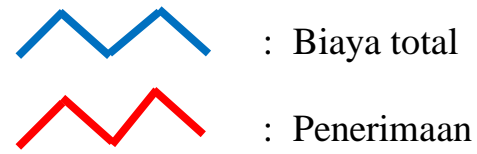

Biaya total merupakan biaya investasi dan biaya operasional yang dikeluarkan selama kegiatan usaha, sedangkan penerimaan usaha berasal dari hasil penjualan produk yang dihasilkan atas kegiatan usaha yang dilakukan. Produk yang dihasilkan dari kegiatan usaha ini adalah telur, limbah dan ayam afkir. Harga jual yang digunakan adalah harga jual yang berlaku saat penelitian yakni untuk telur sebesar Rp16.000,00 per $\mathrm{kg}$, untuk limbah sebesar Rp500,00 per kg, dan untuk ayam afkir sebesar Rp37.000,00 per ekor.

Sumbu y (Q) merupakan nilai biaya total maupun peneriman usaha yang dihitung dalam satuan miliar dan sumbu $\mathrm{x}(\mathrm{t})$ merupakan tahun dari kegiatan usaha ternak ayam ras petelur $\mathrm{CV}$ Mulawarman Farm. Berdasakan pada Gambar 1, menunjukkan bahwa penerimaan usaha setiap tahunnya bersifat fluktuatif yang dipengaruhi oleh tinggi rendahnya tingkat kematian hewan ternak dan perfroma produksi ayam. Penerimaan perusahaan ternak ayam ras petelur CV Mulawarman Farm selalu lebih tinggi dari biaya total kecuali pada tahun ke-1, sebab pada tahun tersebut merupakan tahun pertama perusahaan ternak ini melakukan seluruh investasi dan tahun awal produksi yang berarti biaya total tertinggi terjadi pada tahun tersebut. Penerimaan usaha paling rendah terjadi pada tahun ke-7 atau tahun 2016, sebab pada tahun tersebut tingkat kematian ayam merupakan yang paling tinggi yaitu 12,78 persen.

\section{Kelayakan Finansial}

Analisis kelayakan finansial diteiliti menggunakan kriteria investasi yaitu Net Present Value (NPV), Internal Rate of Return (IRR) dan Payback Period (PP). Analisis finansial dihitung berdasarkan umur ekonomi usaha yaitu 15 tahun dan tingkat suku bunga yang berlaku saat ini yaitu 10,50 persen. Hasil perhitungan analisis kelayakan finansial dapat dilihat pada Tabel 3 .

\section{a. Net Present Value (NPV)}

Analisis NPV bertujuan untuk mengetahui selisih nilai sekarang arus penerimaan dengan nilai sekarang arus biaya. Berdasarkan hasil perhitungan analisis kelayakan finansial, nilai NPV yang diperoleh lebih besar dari nol yaitu Rp18.826.686.773,92 yang menunjukkan bahwa perusahaan ternak tersebut menguntungkan untuk dikembangkan.

\section{b. Internal Rate of Return (IRR)}

Internal Rate of Return (IRR) digunakan untuk mencari tingkat suku bunga yang dapat membuat $\mathrm{NPV}=0$. Nilai IRR yang diperoleh adalah 32,01 persen yang berarti bahwa nilai tersebut lebih besar dari tingkat suku bunga yang berlaku yaitu 9 persen, sehingga usaha ini sangat layak dan menguntungkan untuk dikembangkan.

\section{c. Payback Period (PP)}

Analisis payback period digunakan untuk mengetahui jangka waktu yang diperlukan dalam mengembalikan modal investasi, yang dihitung dari pendapatan.

Beradasarkan Tabel 3, nilai PP yang diperoleh yaitu 4,86 tahun artinya masa pengembalian atas investasi yang dikeluarkan hanya selama 4,86 tahun atau 4 tahun 10 bulan. Nilai dari PP perisahaan ternak tersebut lebih pendek dari umur ekonomis usaha ternak yaitu 15 tahun.

Tabel 3. Hasil perhitungan kelayakan finansial CV Mulawarman Farm

\begin{tabular}{lcc}
\hline \multicolumn{1}{c}{ Kriteria } & Hasil & Keterangan \\
\hline NPV & $18.826 .686 .773,92$ & Layak \\
IRR & $32,01 \%$ & Layak \\
PP & 4,86 & Layak \\
\hline
\end{tabular}


Hal ini berarti bahwa perusahaan ternak ayam ras petelur CV Mulawarman Farm menguntungkan untuk dikembangkan karena mampu mengembalikan modal investasi sebelum umur usaha habis.

\section{d. Analisis BEP}

Hasil analisis BEP harga dan BEP produksi pada perusahaan ternak ayam ras petelur CV Mulawarman Farm yaitu sebesar Rp14.740,00 dan $490.135,00 \mathrm{~kg}$. Hal ini berarti bahwa perusahaan ternak ayam ras petelur CV Mulawarman Farm berada pada titik BEP saat harga jualnya Rp14.740,00 dan produksinya sebesar 490.135,00 $\mathrm{kg}$. Berdasarkan hasil perhitungan tersebut, harga jual telur yang ditetapkan oleh perusahaan ternak ayam ras petelur CV Mulawarman Farm sebesar Rp16.000,00 lebih besar dari BEP harga dan produksi telur yang dicapai yaitu $957.759,00 \mathrm{~kg}$ lebih besar dari BEP produksi. Hal ini menunjukkan bahwa perusahaan ternak ayam ras petelur CV Mulawarman Farm menguntungkan.

\section{Analisis Subsistem Pemasaran}

\section{Saluran Pemasaran Telur dan Distribusi Telur}

Saluran pemasaran yang terbentuk pada kegiatan pemasaran perusahaan ternak ayam ras petelur $\mathrm{CV}$ Mulawarman Farm adalah saluran pemasaran langsung dimana saluran pemasaran langsung pada perusahaan ternak ini hanya melibatkan perusahaan ternak ayam ras petelur $\mathrm{CV}$ Mulawarman Farm selaku produsen dan pelanggan selaku pedagang pengecer serta konsumen tanpa melalui lembaga perantara. Perusahaan ternak ini hanya menjual ke palanggan tetap saja yang berperan sebagai pengecer. Hal ini dimaksudkan untuk menekan biaya-biaya pemasaran yang luas dan menyebar yang tidak mungkin dicapai oleh perusahaan ternak ini.

Secara keseluruhan jumlah pelanggan tetap perusahaan ternak ayam ras petelur $\mathrm{CV}$ Mulawarman Farm berjumlah 26 pelanggan yang tersebar kebeberapa daerah seperti Bandar Lampung, Pringsewu, Tanggamus dan Pesawaran. Banyaknya distribusi penjualan telur kepada pelanggan-pelanggan dari perusahaan ternak tersebut dapat dilihat pada gambar dibawah ini.

\section{Q Distribusi penjualan}

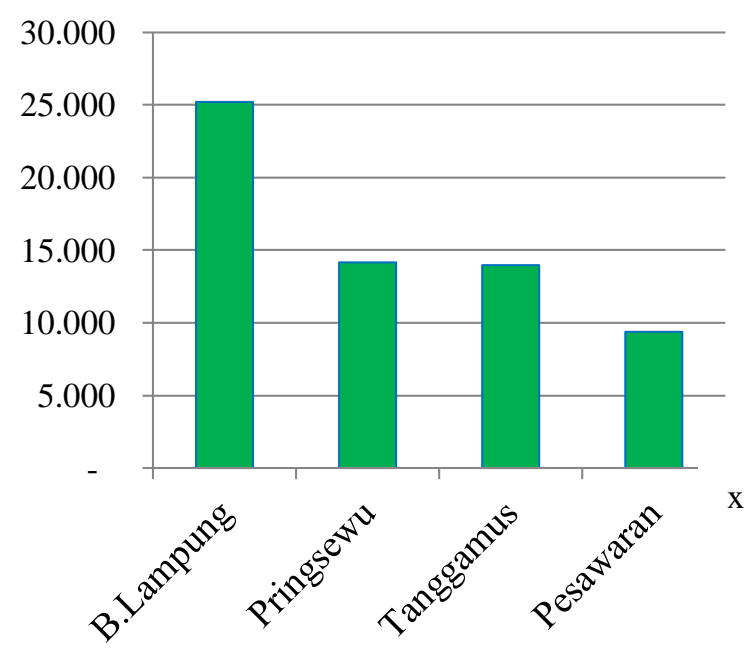

Gambar 2. Volume penjualan telur CV Mulawarman Farm

Volume distribusi penjualan telur ke berbagai daerah berbeda-beda. Berdasarkan hasil penelitian, total penjualan telur CV Mulawarman Farm adalah $62.270 \mathrm{~kg}$ per bulan. Persentase distribusi telur CV Mulawarman Farm di Bandar Lampung merupakan yang tertinggi yaitu sebesar 40,21 persen atau $25.200 \mathrm{~kg}$ dari total seluruh penjualan telur. Tinggi-rendahnya persentase volume penjualan dipengaruh oleh tinggirendahnya permintaan dan daya beli masyarakat yang berbeda di masing-masing daerah maupun banyaknya pelanggan dari CV Mulawarman Farm didaerah tersebut.

\section{Strategi Pemasaran}

Bauran pemasaran merupakan salah satu strategi pemasaran dan yang diterapkan pada perusahaan ternak ayam ras petelur CV Mulawarman Farm terdiri dari 4P (product, price, promotion, place).

\section{a. Produk (Product)}

Telur yang dihasilkan tidak memiliki perbedaan dari telur ayam ras usaha ternak pesaing lainnya baik itu bentuk maupun warnanya (coklat). Ratarata bobot telur yang dipasarkan oleh perusahaan ternak ayam ras petelur CV Mulawarman Farm yaitu sebesar 63,84 gram. Hal ini sesuai dengan pendapat Benjamin (1960) yaitu bobot telur ayam bervariasi antara $35-70$ gram. 
Tabel 4. Hasil perhitungan analisis Break Event Point CV Mulawarman Farm

\begin{tabular}{clr}
\hline No & \multicolumn{1}{c}{ Uraian } & \multicolumn{1}{c}{ Jumlah } \\
\hline 1. & Biaya tetap $(\mathrm{Rp})$ & $1.265 .500 .000,00$ \\
2. & Biaya variabel $(\mathrm{Rp})$ & $12.848 .845 .797,50$ \\
3. & Biaya total $(\mathrm{Rp})$ & $14.114 .345 .797,50$ \\
4. & Produksi telur $(\mathrm{kg})$ & $957.579,00$ \\
5. & Harga telur $(\mathrm{Rp} / \mathrm{kg})$ & $16.000,00$ \\
6. & Penerimaan telur $(\mathrm{Rp})$ & $15.321 .260 .160,00$ \\
7. & Penerimaan total $(\mathrm{Rp})$ & $17.471 .274 .272,00$ \\
\hline BEP Produksi $(\mathrm{kg})$ & $490.135,00$ \\
BEP Harga $(\mathrm{Rp})$ & $14.740,00$ \\
\hline
\end{tabular}

\section{b. Harga (Price)}

Harga jual telur pada perusahaan ternak ayam ras petelur CV Mulawarman Farm sebesar Rp16.000,00 per kg. Penentuan harga jual telur tersebut berdasarkan perhitungan biaya-biaya yang telah dikeluarkan selama kegiatan usaha berjalan yang ditambahkan besaran persentase keuntungan yang diharapkan serta sesuai dengan harga jual yang ditetapkan oleh Pinsar Petelur Nasional (PPN) Provinsi Lampung.

\section{c. Tempat (Place)}

Cakupan wilayah pemasaran telur perusahaan ternak ayam ras petelur CV Mulawarman Farm adalah pasar lokal yaitu daerah yang masih ada di Provinsi Lampung. Pemasaran produk ditujukkan kepada pelanggan tetap yang berlokasi di berbagai pasar tradisional maupun membuka kios sendiri di daerah Bandar Lampung, Pringsewu, Tanggamus dan Pesawaran. Pemasaran telur dilakukan oleh perusahaan ternak ayam ras petelur $\mathrm{CV}$ Mulawarman Farm secara mandiri.

\section{d. Promosi (Promotion)}

Variabel promosi terdiri dari advertising, public relations, personal selling, direct marketing (Kotler 1997). Promosi adalah suatu kegiatan pemasaran yang bertujuan untuk memperkenalkan produk yang dihasilkan dengan tujuan menarik minat konsumen untuk membeli produk tersebut. Perusahaan ternak ayam ras petelur $\mathrm{CV}$ Mulawarman Farm tidak melakukan kegiatan promosi karena perusahaan ini menghasilkan produk yang dikonsumsi oleh semua masyarakat (barang konsumsi), sudah memiliki pelanggan tetap dan usaha ternak ini sudah berdiri sejak lama. Jadi, kegiatan promosi tidak dilakukan dan jika dilakukan hanya akan menambah biaya promosi.

\section{Prospek Pemasaran Telur}

Prospek pemasaran telur pada perusahaan ternak ayam ras petelur CV Mulawarman Farm memiliki potensi yang cukup menjanjikan khususnya di Kabupaten Pringsewu. Faktor yang mempengaruhi selain telur yang merupakan barang konsumsi dan telah menjadi bahan pangan yang dibutuhkan oleh masyarakat sebagai sumber protein yang terjangkau, didukung juga oleh tersebarnya usaha pengolahan makanan yang berbahan dasar telur. Hal ini dapat dilihat dari meningkatnya penjualan telur selama empat bulan terakhir yaitu Januari April yang disajikan pada Tabel 5.

\section{Analisis Jasa Layanan Pendukung}

\section{Bank}

Perusahaan ternak ayam ras petelur CV Mulawarman Farm dalam menjalankan kegiatan usahanya menggunakan modal pribadi tanpa bantuan atau pinjaman dari bank maupun lembaga keuangan lainnya. Bank dimanfaatkan oleh pemilik usaha penyimpanan dan penarikan uang. Hasil penelitian ini sejalan dengan penelitian yang dilakukan oleh Susanti, Lestari, dan Kasymir (2017) yang menyatakan bahwa bank sebagai lembaga yang bergerak dibidang dana dan permodalan tidak berperan terhadap kegiatan agribisnis, karena modal yang digunakan berasal dari modal pribadi.

\section{Lembaga Pendidikan}

Perusahaan ternak ayam ras petelur CV Mulawarman Farm menerima siswa maupun mahasiswa 2 kali setiap tahun dengan kuota maksimal 8 orang. Kegiatan praktik lapangan maupun penelitian tersebut secara tidak langsung memberikan dampak positif berupa informasi, masukan-masukan maupun temuan baru yang bermanfaat serta dapat membantu meringankan tugas operator kandang dan saling berbagi pengalaman dan ilmu.

Tabel 5. Volume penjualan telur periode JanuariApril 2017

\begin{tabular}{clc}
\hline No & Bulan & $\begin{array}{c}\text { Volume penjualan } \\
(\mathrm{kg})\end{array}$ \\
\hline 1. & Januari & $13.670,00$ \\
2. & Februari & $13.800,00$ \\
3. & Maret & $13.810,00$ \\
4. & April & $14.145,00$ \\
\hline
\end{tabular}




\section{Sarana Transportasi}

Sarana transportasi jalan yang digunakan sebagai jalur pemasaran hasil produk dari kegiatan usaha ternak ayam ras petelur CV Mulawarman Farm sudah baik, hal ini dilihat dari kondisi jalan yang sudah diaspal dan mampu dilewati kendaraan kecil maupun besar disekitar lokasi usaha ternak tersebut.

\section{Pinsar Petelur Nasional (PPN) Lampung}

Pemilik perusahaan ternak ayam ras petelur $\mathrm{CV}$ Mulawarman Farm merasa diuntungkan dengan menjadi anggota PPN, sebab selain PPN membantu menstabilkan harga antar peternakpeternak yang tergabung dalam keanggotaan, pemilik CV Mulawarman Farm juga dapat bertukar informasi dengan peternak lainnya mengenai cara budidaya yang baik, penanganan penyakit ternak, jenis pakan yang sesuai, peralatan penunjang yang bertujuan untuk pengembangan dan kemajuan usaha ternaknya.

\section{KESIMPULAN}

Berdasarkan hasil penelitian dan pembahasan dapat disimpulkan bahwa pengadaan sarana produksi CV Mulawarman Farm belum sepenuhnya sesuai dengan yang diharapkan, sebab pengadaan nipple drinker masih mengalami keterlambatan karena jaraknya yang jauh. Pengembangan usaha pada perusahaan ternak ayam ras petelur CV Mulawarman Farm masih cukup menguntungkan sampai dengan skala populasi 75.000 ekor (25 persen lebih besar dari populasi sebelumnya). Sistem pemasaran telur pada CV Mulawarman Farm didistribusikan kepada pelanggan-pelanggan tetap yang tersebar di berbagai lokasi di Bandar Lampung, Pringsewu, Tanggamus, dan Pesawaran dengan persentase distribusi penjualan telur tertinggi yaitu di Bandar Lampung.

\section{DAFTAR PUSTAKA}

Arifin B. 2005. Pembangunan Pertanian : Paradigma Kebijakan dan Strategi Revitalisasi. PT Grasindo. Jakarta.

Benjamin. 1960. Marketing Poultry Products. New York-London.

BPS Lampung. 2015. Provinsi Lampung Dalam Angka 2015. BPS Provinsi Lampung. Lampung.

Benjamin. 1960. Marketing Poultry Products. New York-London.

Dinas Peternakan dan Kesehatan Hewan Provinsi Lampung. 2008. Komoditas Peternakan Provinsi Lampung. Provinsi Lampung.

Genetics. 2009. Isac Brown Management Guide. A Hendrix Genetics Company. Netherland.

Hidayat YS, Sulaksana J, dan Sumantri K. 2016. Analisis sistem agribisnis ayam ras petelur. Jurnal Universitas Majalengka. 4 (1): 29 38. http://jurnal.unma.ac.id/index.php/AG/ article/ download/ 395/376. [7 Januari 2017].

Kata Data News and Research. 2015. Ayam Ras Pasok 71 Persen Konsumsi Telur Masyarakat. https://databoks.katadata.co.id/datapublish. [21 Agustus 2016].

Kotler P. 1997. Manajemen Pemasaran. Prenhalindo. Jakarta.

Suci B, Abidin Z, dan Kalsum U. 2016. Analisis finansial usaha ternak ayam probiotik : studi kasus: KPA Berkat Usaha Bersama, Kota Metro. JIIA. 4 (1): 15 - 23. http://jurnal .fp.unila.ac.id/index.php/JIA/article/view/121 0. [15 Juli 2017].

Susanti S, Lestari DAH, dan Kasymir E. 2017. Analisis sistem agribisnis ikan patin (Pangasius sp) Kelompok Budidaya Ikan Sekar Mina di Kecamatan Kota Gajah Lampung Tengah. JIIA. 5 (2): 116 - 123. http://jurnal.fp.unila.ac.id/index.php/JIA/articl e/view/1648/1474. 33. [25 Desember 2017]. 